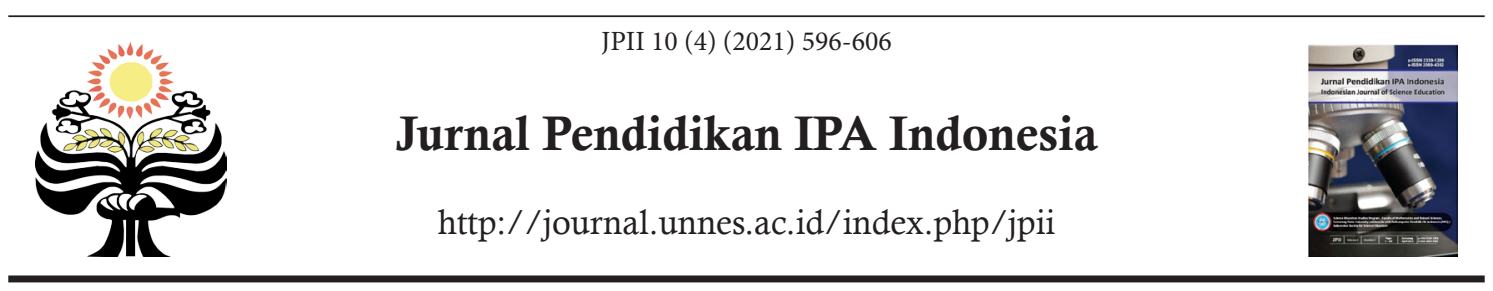

\title{
MARKOV ANALYSIS OF WATER DISCHARGE AS AN INDICATOR OF SURFACE WATER SECURITY OF THE BANDUNG BASIN
}

\author{
S.Wulandari*1, A. Sabar ${ }^{2}$, T. Setiadi ${ }^{3}$, B. Kurniawan ${ }^{4}$ \\ ${ }^{1,2}$ Faculty of Civil and Environmental Engineering, Institut Teknologi Bandung, Indonesia \\ ${ }^{3}$ Faculty of Industrial Technology, Institut Teknologi Bandung, Indonesia \\ ${ }^{4}$ Ministry of Environtment and Forestry, Indonesia
}

DOI: 10.15294/jpii.v10i4.28974

Accepted: February $10^{\text {th }} 2021$. Approved: December $27^{\text {th }} 2021$. Published: December $31^{\text {st }} 2021$

\begin{abstract}
Water security is the fulfillment of access to adequate and sustainable water needs (quantity and quality) for the growth of human and ecosystem life and the ability to reduce risks associated with water. By knowing the water security of an area, efforts to conserve, utilize, control destructive force, develop information systems and participate in the community can be assessed to what extent and how the management has been carried out. The purpose of this research is to formulate the amount of water availability per capita (quantity) of surface water and to determine the quantity of the worst water quality at a critical time (the worst quantity) to be used as a reference in determining the amount of water resistance for development. The only observed water quality was the BOD (Biological Oxygen Demand) organic pollutant value in the dry year in the dry season using the Markov Chain Method. Water security in the Bandung Basin is currently classified as bad (rare) because the water availability index figures only indicate $174 \mathrm{~m} 3$ per capita per year (quantity). Meanwhile, data on the quality value of BOD (Biological Oxygen Demand) pollutants in dry years (R5) of $129 \mathrm{mg} / 1$ and very dry years (R10) of 112 $\mathrm{mg} / 1$ which has also exceeded the class I quality standard of PP No. 22/2021 (> $2 \mathrm{mg} / \mathrm{l})$ regarding water quality management and pollution control which is designated for raw water needs drinking water. Changing water use patterns and promoting effective implementation of integrated water resources management are essential strategies for increasing water security in Indonesia.
\end{abstract}

(C) 2021 Science Education Study Program FMIPA UNNES Semarang

Keywords: water security; markov model; water availability; pollution control

\section{INTRODUCTION}

Water security is the fulfillment of access to adequate and sustainable water needs (quantity and quality) for the growth of human and ecosystem life and the ability to reduce risks associated with water (Cook \& Bakker, 2012; Bakker, 2012; Falkenmark, 2013; Garrick \& Hall, 2014; Wheater \& Gober, 2015; Radhika \& Hatmoko, 2017; Hoekstra et al., 2018). Water security is a prerequisite for food and energy security (Hanjra \& Qureshi, 2010; Head \& Cammerman, 2010; Lautzhe \& Manthrithilake, 2012; Gössling et al.,

*Correspondence Address

E-mail: wulandari.suci@gmail.com
2012; van Noordwijk et al., 2016). The interaction between the three factors that form the condition of water resources (natural factors, anthropogenic factors (human activities), and administrative and managerial factors is vital to maintain a large amount of water security (Bakker, 2012; Wheater $\&$ Gober, 2015). By knowing the water security of an area, efforts to conserve, utilize, control destructive force, develop information systems and participate in the community can be assessed to what extent and how the management has been carried out (Cook \& Bakker, 2012). Although all the world communities agree that water security needs to be paid attention to, both for water resources management and sustainable develop- 
ment in general, there is no agreement on how to define water security. It had not been agreed on the value of minimum water security until recently so that households, cities, watersheds, and countries can develop sustainably without worrying about possible droughts and floods (Cook \& Bakker, 2012; Bakker, 2012; Radhika \& Hatmoko, 2017; Thapa et al., 2018). The amount of water availability has been calculated from the availability of water based on the potential annual rainfall and the population in the area (Indonesian National Water Resources Council, 2012).

The hydrological component consists of random and stochastic rainfall and discharge (Sabar, 2009; Marganingrum, 2013; Corsita, 2014; Louck \& Van Beek, 2017; Marselina \& Sabar, 2017). The amount of rainfall is more independent than the discharge, which depends on land cover. So that the discharge, in this case, the planned discharge, is more appropriately used as a basis for determining the amount of water security compared to the amount of potential rainfall. One method of determining the discharge plan and forecasting future discharge that is easy, simple, and has a reasonably accurate correlation in Indonesia is the Markov Chain method. Markov discrete model is a discrete stochastic model in decision making, where time $t$ will affect decisions taken at a future time $(\mathrm{t}+1)$ (Sabar, 2009; Nuraeni, 2011; Marganingrum, 2013; Corsita, 2014; Setyono \& Ismijayanti, 2015; Louck \& Van Beek, 2017; Marselina \& Sabar, 2017).

Data retrieved from the Director-General of Water Resources of the Ministry of Public Works and Housing (2016) show the current amount of water availability in Indonesia only covers $56 \mathrm{~m}^{3}$ per capita per year. This number is considered very small. Falkenmark (1989) and WHO (2014) state that a country is categorized to be very scarce if it has less than $500 \mathrm{~m}^{3}$ of water per capita per year. The fact is in contrast to Indonesia's status in the top 5 countries, according to $\mathrm{WHO}$, which has the highest volume of renewable water (under Brazil, Russia, and Canada).

Indonesia is in a tropical climate with high temperatures and rainfall. In this region, there are two changes of seasons in a year, the dry season and the rainy season. Despite its abundant water resources, Indonesia continually experiences water shortages due to climate variability, geographical condition, and dry season (Fulazzaky, 2014; Afifah et al., 2019). The annual climate variation pattern may affect water availability and water quality unequally, possibly constraining the water use with its unbalanced conditions of demands and the available potential, particularly during the dry season (Bulsink et al., 2010; Hanjra \& Qureshi, 2010; Fischer et al., 2015; Afifah et al., 2019). The groundwater potential is abundant in Indonesia. Unfortunately, due to limited groundwater facilities and infrastructure, Indonesia still relies on surface water as its water source, and groundwater is used only as a reserve (Indonesian National Water Resources Council, 2012). One of the primary and super-priority watersheds due to its strategic nature in Indonesia is the Citarum watershed in West Java Province.

The Citarum Watershed (DAS) is the main watershed in West Java which has a high area of critical land and is strategic because it supports the capital city of Jakarta. The watershed covering 6,614 square kilometers, or $22 \%$ of the West Java area is the watershed with the most populous population in West Java. The upstream of the Citarum river is Mount Wayang, which is part of the Bandung Basin. The Citarum watershed is located in an area affected by the Monsoon climate, which is characterized by one rainy peak and one dry peak in a year, where there are several consecutive months of rain or dryness, so the potential for rainwater during the rainy season needs to be optimized (Sabar, 2009; Cook \& Bakker, 2012; Radhika \& Hatmoko, 2017).

The critical potential of the Citarum watershed is currently threatened by a decrease in the quality of river water due to the increasing pollution load, which has exceeded the capacity of the water source. The Bandung Basin, which consists of 4 Regencies and Cities (Kab. Bandung, Kota Bandung, Kab. Sumedang, and Kab. West Bandung), contributes to considerable domestic, agricultural, and industrial waste pollution in the Citarum River (Supangat \& Paimin, 2007; Marselina \& Sabar, 2017). This pollution can be seen from the increase in levels of biological oxygen demand (BOD) and the decreased levels of dissolved oxygen (DO) from upstream to downstream after crossing the boundary of the Bandung Basin in Nanjung. It shows that the pollution of organic matter measured with BOD parameters is the primary source of pollutants that need priority treatment to control water pollution (Bukit, 2002). BOD (Biological Oxygen Demand) is a number that shows the amount of oxygen needed by microorganisms to carry out the process of decomposition of organic pollutants in an aerobic state (Priyambada \& Suprapto, 2008). BOD measures the "strength" of water or wastewater: the greater the concentration of ammonia-nitrogen or degradable organic carbon, the higher the BOD. The efficiency of BOD re- 
moval is a standard performance characteristic of wastewater-treatment plants, and BOD is a major feature of treatment-plant discharge permits (Mihelcic et al., 1999). BOD in this study is only used as an example in determining water security in terms of quality. The same method can be carried out for all the required water quality parameters.

Based on the various problems and challenges raised, it is important to know the amount of water security in an area, which can then be used as a reference in making policy directions, targets, and strategies for water security and water resources management so that the potential for conflict can be minimized. The purpose of this research is to formulate the amount of water availability per capita (quantity) of surface water in rivers and reservoirs and to determine the quantity of the worst water quality at a critical time (the worst quantity) to be used as a referen- ce in determining the amount of water security for development. The only observed water quality was the BOD (Biological Oxygen Demand) organic pollutant value in the dry year in the dry season using the Markov chain method.

\section{METHODS}

The study was carried out in the Bandung Basin, especially in the Nanjung and Saguling Reservoir Turbine Intake monitoring post. Both monitoring posts are located in the lower part of the Bandung Basin, i.e., the Citarum River upstream. Nanjung Post is located in the flow of Citarum River upstream, right before the Saguling Reservoir inlet. This area is located between Bandung Regency, Bandung City, and Cimahi. At the same time, the Intake Post of the Saguling Reservoir is in the Saguling Reservoir.

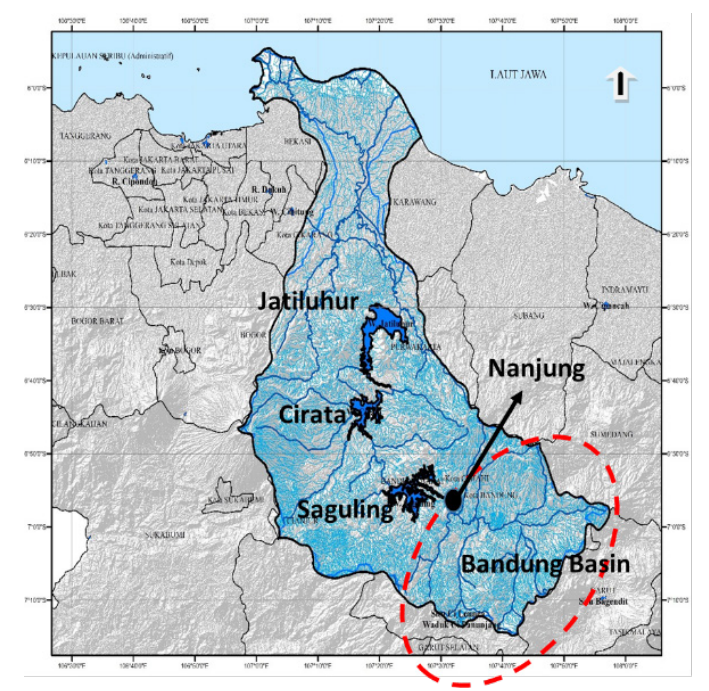

Figure 1. Map of Citarum Watershed

There are differences in water conditions in both monitoring and research posts. The turbine Intake Post is in the Saguling Reservoir with a water discharge adjustment and a track (volume). Meanwhile, the Nanjung post is in the river in which the quantity of water is very dependent on the water discharge (natural) with a relatively smaller amount compared to the input discharge of the Saguling Reservoir.

The data used in this study is secondary data from the manager of the Saguling Reservoir, i.e., Indonesia Power Saguling. The discharge data used is monthly data from 1986-2013. In comparison, water quality data uses quarterly data (March, June, September, and December) from 1999-2013. The water quality data used is also limited to BOD (Biological Oxygen Demand) parameter data only. In the Markov process, the amount of water discharge entering the reservoir is simplified by dividing it into three classes and five classes. Based on the division of water discharge classes, an attempt is made to trace the historical record of water discharge events so that each month a stochastic matrix can be made, which divides the water discharge class that enters the reservoir into 3 classes and 5 classes (Sabar, 2009; Nuraeni, 2011; Marganingrum, 2013; Corsita, 2014; Setyono \& Ismijayanti, 2015; Marselina \& Sabar, 2017; Afifah et al., 2019).

For division into three classes, the data are simplified into 3 parts (Figure 2): dry year (represented by 0 ), normal year (represented by 1 ), and wet year (represented by 2). The procedure for obtaining the transition matrix begins with determining the number of class divisions and then entering the historical discharge data into the class divisions according to the specified class limits. After that, look for the probability value of 
the event $j$ at time $t_{n}$ occurs when the event occurs at time $t_{n-1}$ and the last one, build a transition matrix with elements of each row and column from the calculation of the transition probability at the time under review.

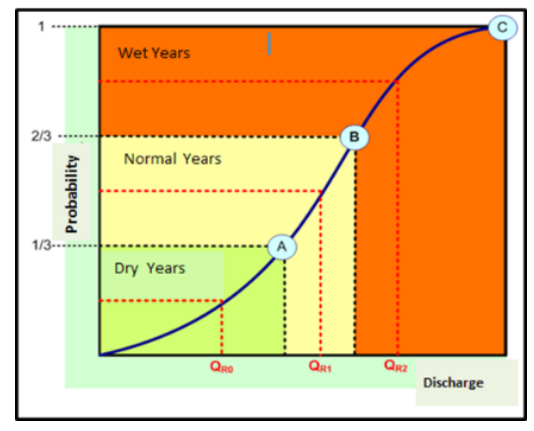

Source: Sabar (2009)

Figure2. Discharge Classification Based on Probability (Markov Model) 3 Classes

The determination of the class interval for each class division is obtained by dividing the probability curve of the selected population distribution into 3 equal parts, namely $0.333,0.667$, and 1, as shown in Figure 2. The range value of each class is the middle value on the probability curve of $0.333,0.667$, and 1 . The probability of each data was determined using the Weibull method (Sabar, 2009; Marganingrum, 2013; Corsita, 2014; Marselina \& Sabar, 2017).

For division into five classes, the data are simplified into 5 parts (Figure 3.), namely: a very dry year (represented by 0 ), dry year (represented by 1 ), normal year (represented by 2 ), wet year (represented by 3), and a very wet year (represented by 4 ).

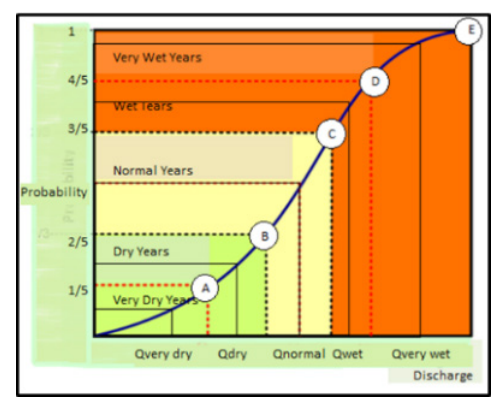

Source: Sabar (2009)

Figure 3. Discharge Classification Based on Probability (Markov Model) 5 Classes

Determining the class interval for each class division is obtained by dividing the probability curve from the selected population distribution into five equal parts, namely $0.2 ; 0.4 ; 0.6 ; 0.8$; and 1.
Analysis of quantity and quality is focused on dry discharge plan (R5) or equivalent to discrete dry Markov 3 class and also dry discharge plan (R10) or equivalent to very dry years of discrete Markov 5 class as required as drinking water design criteria, i.e., discharge dry plan for R10-20 years (Sabar, 2009; Nuraeni, 2011; Marganingrum, 2013; Corsita, 2014; Marselina \& Sabar, 2017; Afifah et al., 2019). Water (2016) uses per capita water resources indicators to show the imbalance between freshwater resources and the population or the risk of scarcity of freshwater resources for the community. This indicator is then used in determining water security in terms of quantity (amount). Water security, in terms of quantity of water, can be seen by comparing the availability of water with a reliable discharge compared to the amount of water demand per capita. Household, urban, and industrial water requirements are calculated based on population.

The index of water availability per capita has been commonly used in various countries, such as Sullivan (2003) and Radhika et al. (2013). Table 1 describes the conditions based on the index of water availability per capita. Index of Water Availability Per Capita = Availability of water ( $\mathrm{m}^{3} /$ year)/Total population (person).

Table 1. Water scarcity Conditions

\begin{tabular}{ll}
\hline $\begin{array}{c}\text { Index of Water } \\
\text { Availability/Capita }\left(\mathrm{m}^{3} /\right. \\
\text { year/capita) }\end{array}$ & \multicolumn{1}{c}{ Condition } \\
\hline More than 1.700 & No stress \\
$1.000-1.700$ & Stress \\
$500-1.000$ & Scarcity \\
Less than 500 & Absolute scarcity \\
\hline Source: Water (2016) &
\end{tabular}

Water security in terms of quality is obtained by comparing water quality at the discharge monitoring post. It has been classified based on the dry and very dry years using the Markov Chain method, with Najung water quality and the Saguling Reservoir Turbine Intake with class I quality standard of PP No. 22/2021 on Water Quality Management and Pollution Control intended for drinking water. The classification of dry years (R5, 3 classes) and very dry years (R10, 5 classes) selected is determined based on dry year input discharge from the Saguling Intake Reservoir post and Nanjung post in 1999-2013 based on the data availability. 


\section{RESULTS AND DISCUSSION}

Water security is closely related to food and energy securities. It causes a high conflict of interest in water management (Hanjra \& Qureshi, 2010; Head \& Cammerman, 2010; Lautzhe \& Manthrithilake, 2012; Gössling et al., 2012; van Noordwijk et al., 2016). In addition, if the high-water demand is not balanced with adequate clean water infrastructure, it will lead to water scarcity (Vörösmarty et al., 2010; Zeitoun et al., 2010; Fischer et al., 2015; Wheater \& Gober, 2015; Thapa et al., 2018). Water (2016) states that around 780 million people do not have access to clean water, and 80 million are in Indonesia. Access to clean water can then exacerbate people's access to proper sanitation. With limited water availability in space and time, knowing how to use water effectively and efficiently is crucial.

The study of water security begins by finding the amount of water available by looking for mainstay discharge at the study site. Afterward, the calculation of the water availability can be done by looking for the discharge of the Nanjung and Saguling Reservoir historical mainstay discharge using the Markov method as shown in Table 2 and 3 , respectively.

Table 2. Data of Historical Mainstay Discharge in the Nanjung Post from 1986-2013

\begin{tabular}{ccc}
\hline Reliable Discharge & Prob & Monthly Average \\
\hline R20 Wet Years & $5 \%$ & 153.91 \\
R10 Wet Years & $10 \%$ & 123.18 \\
R5 Wet Years & $20 \%$ & 101.31 \\
R2 Normal Years & $50 \%$ & 70.43 \\
R5 Dry Years & $80 \%$ & 44.67 \\
R10 Dry Years & $90 \%$ & 32.12 \\
R20 Dry Years & $95 \%$ & 25.14 \\
\hline
\end{tabular}

From Table 2, it can be seen that the values of the mainstay discharge available in the Nanjung Post R10-20 during the dry year are 32.12 and $25.14 \mathrm{~m}^{3} / \mathrm{sec}$, respectively. Meanwhile, from
Table 3, it is known that the values of a historical mainstay in the Saguling reservoir R10-20 during the dry year are 41.50 and $32.85 \mathrm{~m}^{3} / \mathrm{sec}$, respectively.

Table 3. Data of Historical Mainstay Discharge in the Saguling Reservoir from 1986-2013

\begin{tabular}{ccc}
\hline Reliable Discharge & Prob & Monthly Average \\
\hline R20 Wet Years & $5 \%$ & 188.17 \\
R10 Wet Years & $10 \%$ & 157.46 \\
R5 Wet Years & $20 \%$ & 125.91 \\
R2 Normal Years & $50 \%$ & 86.32 \\
R5 Dry Years & $80 \%$ & 56.87 \\
R10 Dry Years & $90 \%$ & 41.5 \\
R20 Dry Years & $95 \%$ & 32.85 \\
\hline
\end{tabular}

Both quantities are following the design criteria for raw drinking water from the Indonesian Ministry of Public Works. Therefore, the reliability of the water quantity/amount of water availability calculated in the Nanjung and Saguling Reservoir has been under the required criteria.

Table 4. Design Criteria for Surface Raw Water Allocation

Surface Water Source

Raw Water Allocation Design Criteria

\begin{tabular}{cccc}
\hline & \multicolumn{2}{c}{ Domestic Municipality Industry (DMI) } & Irrigation \\
\cline { 2 - 3 } Dry Water Discharge & $\mathrm{R}=10-20$ years & $15-30$ days & $\mathrm{R}=5$ years \\
& & & \\
\hline Source: Modification of design criteria for MBA PU Cipta Karya raw water (Sabar, 2009)
\end{tabular}


The population in the Bandung Basin retrieved from BPS data (2011) is 5.8 million people spread across 56 sub-districts in Bandung City, Cimahi City, Bandung Regency, West Bandung, and Sumedang Regency. If we calculate the water security from the water availability per capita per year, the value is obtained (using the reliable discharge data in the Nanjung Post R10 during the dry year at $32.12 \mathrm{~m}^{3} / \mathrm{sec}$ ):

Index of water availability $=1,012,936,320 \mathrm{~m}^{3} /$ year $/ 5,800,000$ people $=174 \mathrm{~m}^{3}$ per capita per year

From this index, it can be seen that the absolute water scarcity (based on Table 1) in the Bandung Basin, which causes water security in the Bandung Basin, falls into the poor (rare) category.

This mainstay discharge quantity must also be reanalyzed every five years. The land changes that have occurred in the Bandung Basin, due to the establishment of the Bandung Basin in the National Strategic Area, have caused rain variability and decreased discharge sensitivity. The exploitation of land has disrupted the balance of the main components of hydrology (rain and discharge). Marganingrum (2013) shows that the monthly rainfall average from 19501980 in the Bandung Basin was $182 \mathrm{~mm} / \mathrm{month}$. Nevertheless, from 1986-2008, the monthly rainfall average fell to $139 \mathrm{~mm} / \mathrm{month}$. Changes in average values indicate variability or uncertainty of rain (Sabar, 2009; Marganingrum et al., 2013). Rainfall (P) is a random variable. Rain with a random character will also be a flowrate with a random nature (even though rain is more independent than discharge). Discharge extremity is indicated by a more extreme difference between the minimum and maximum discharges. The minimum daily discharge in the Nanjung Post is getting lower, whereas the maximum daily discharge is getting higher. Discharge analysis of the minimummaximum plan (dry-wet) is fundamental in the planning and evaluating water resources infrastructure (Marganingrum, 2013; Marselina \& Sabar, 2017).

The average monthly discharge is used to determine the fluctuations in water flow over time which also affects the quality of raw water, especially related to pollution dilution factors. From both Figure 4 and 5 , it can also be seen the discharge fluctuations in the Nanjung Post and the water volume fluctuations in the Saguling Reservoir where the lowest points occur in October-November or between period III of water quality monitoring samples (September) and IV (December). Therefore, the analysis of water quality needs to pay attention to the condition of the discharge and volume of the reservoir and the classification of the corresponding discharge year, namely classification of the very dry year (5 classes), which is analogous to the mainstay discharge of R10 dry year.

Disposal of wastewater can threaten water security by contaminating limited available freshwater. $75 \%$ of the Saguling Reservoir intakes comes from the record of measured discharge in the Nanjung Post so that the classification of dry, normal, and wet year can be uniform (Supangat \& Paimin, 2007; Sabar, 2009; Marganingrum, 2013; Corsita, 2014; Marselina \& Sabar, 2017). The sampling year classification in 3 classes is based on the discharge quantity of the Markov discrete method, as shown in Table 5 and Table 6.

Table 5. Year Classification of Water Quality Monitoring Based on Dry, Normal, Wet Discharge (3 Classes)

\begin{tabular}{ccc}
\hline Category & Discharge Range $(\mathrm{m} 3 / \mathbf{s})$ & Year \\
\hline Wet & $88,29<\mathrm{Q} 2$ & $2001,2005,2007,2010,2013$ \\
Normal & $78,67<\mathrm{Q} 1<84,90$ & $1999,2000,2008,2009,2012$ \\
Dry & $\mathrm{Q} 1<77,49$ & $2002,2003,2004,2006,2011$ \\
\hline
\end{tabular}

Based on Table 5 and Table 6, dry years (3 classes) were in 2002, 2003, 2004, 2006, and 2011, and very dry years (R10, 5 classes) were in
2003, 2006, and 2011. The quality analysis performed on BOD pollutant parameters is carried out on the data in the dry year. 
Table 6. Year Classification of Water Quality Monitoring Based on Very Dry, Normal, Wet, and Very Wet Discharge (5 Classes)

\begin{tabular}{ccc}
\hline Category & Discharge Range $(\mathrm{m} 3 / \mathbf{s})$ & Year \\
\hline Very Wet & $>109,44$ & $2001.2010,2013$ \\
Wet & $84,90-95,13$ & $1999,2005,2007$ \\
Normal & $79,20-84,60$ & $2008,2009,2012$ \\
Dry & $68,46-78,67$ & $2000,2002,2004$ \\
Very Dry & $<65,88$ & $2003,2006,2011$ \\
\hline
\end{tabular}

First, to determine the difference in the quantity of river flow and reservoir conditions regarding water quality conditions, historical discharge data in the Nanjung post and Saguling Reservoir Intake with BOD parameters are shown in Figure 4 and Figure 5.

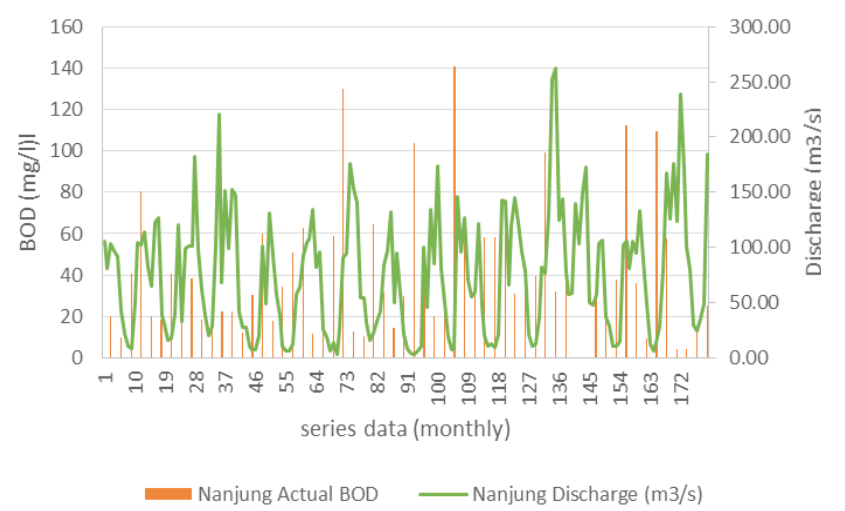

Figure 4. Monthly Historical Data of Discharge and BOD in the Nanjung Post (1999-2013)

Figure 4 shows the comparison between and BOD value $(\mathrm{mg} / \mathrm{l})$ in Pos Nanjung, upstream monthly historical data of water discharge $\left(\mathrm{m}^{3} / \mathrm{s}\right)$ of the Citarum river.

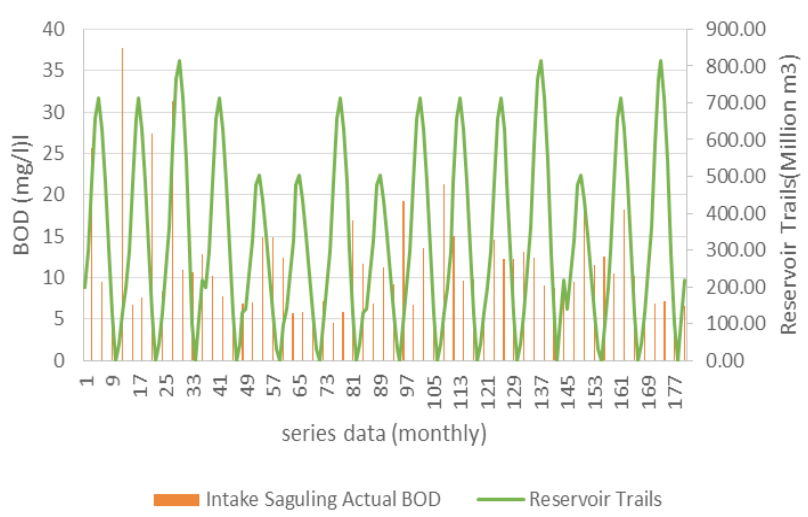

Figure 5. Monthly Stock Volume and BOD Historical Data in the Saguling Turbine Intake Post (19992013)

Figure 5 shows the comparison between monthly reservoir stock volume (million $\mathrm{m}^{3}$ ) and 
Ideally, water quality indicated by the concentration of several water quality parameters is a function of water quantity. During the conditions of low quantity, assuming the pollution load is controlled and constant, there is an increase in the concentration level of pollutants. On the contrary, during the condition of quantity (discharge or volume) is high, there will be a decrease in pollutant concentration level due to dilution. However, Figure 4 and Figure 5 show that uncertainties do not achieve ideal conditions in the level of pollutant concentration with an increase/decrease in the quantity of water that occurred. This shows that pollution control has not run optimally in these waters; in this case, both in Nanjung Post (river) and Saguling Reservoir Turbine Intake Post.

Sitorus \& Simangunsong (2013) states there are more than 10 (ten) regulations starting from the law up to the applicable district regulations and regulating current pollution control efforts. These various regulations should have been able to protect and preserve the designation or function of water bodies for the benefit of the commu- nity. However, the fact is that losses due to deteriorating river water quality increase in intensity and frequency. In many cases, the disposal of industrial waste in Indonesia is legal because there is a permit to dispose of wastewater that does not exceed its quality standards. However, pollution and various issues that accompany it still occur. Therefore, it should be suspected that one of the main sources of this pollution problem is in the regulations of the licensing and quality standards of wastewater which does not function to protect and preserve the designation of a waterbody.

Subsequent analyses are then carried out by classifying the BOD values in dry years (R5, Markov 3 classes) and very dry years (R10, Markov 5 classes) based on the classification of Markov discharge data that has been carried out on the processing of discharge/quantity of water data. The BOD value data is then compared with the value of the BOD parameter in the class I quality standard of PP No. 22/2021 (2 mg/l) regarding the Implementation of Environmental Protection and Management. The results are shown in the following Figure 6 and Figure 7.

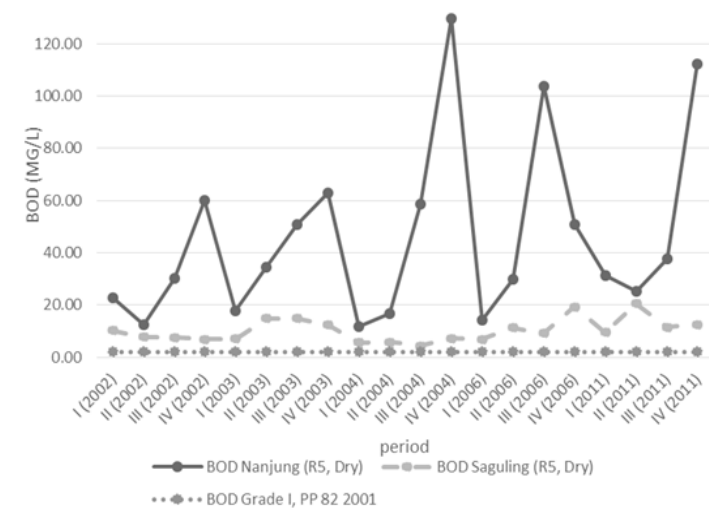

Figure 6. Graphic of BOD Quality Parameter for Dry Years (R5) in the Nanjung Post and Saguling Reservoir Turbine Intake

From Figure 6 and Figure 7, almost all parameters of biochemical oxygen demand (BOD) for dry years (R5, 3 classes) and very dry years (R10, 5 classes) pass quality standards class I of PP No. 22/2021 (>2 mg/l) for drinking water.
The BOD parameter value in the Nanjung post is higher than the BOD value at the Saguling Reservoir Turbine Intake Post. The BOD parameter values in the Saguling Reservoir Intake post are also relatively stable.

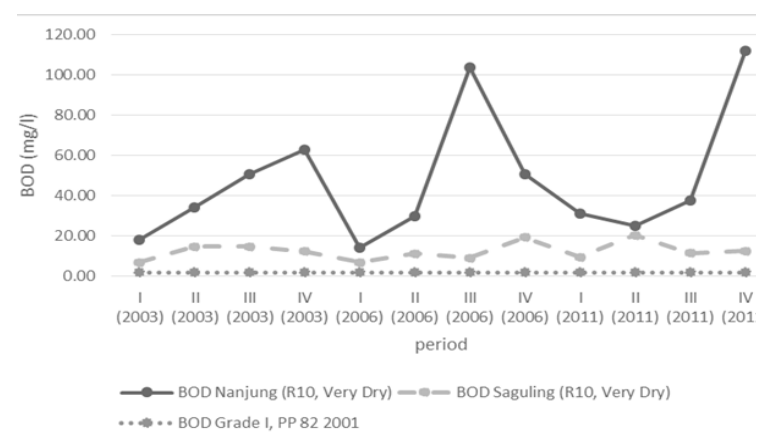

Figure 7. Graphic of BOD Quality Parameters for Very Dry Years (R10) in the Nanjung post and Saguling Reservoir Turbine Intake 
If it is analyzed further by assuming a controlled and constant pollutant load, the BOD value in the very dry year (R10) should be higher than the value during the dry year (R5). Meanwhile, Figure 6 and Figure 7 show different things. The highest $\mathrm{BOD}$ value was during the dry year (R5), i.e., 2004, which showed a BOD value reaching $129 \mathrm{mg} / 1$ while the BOD value in the very dry year only reached $112 \mathrm{mg} / 1$, i.e., 2011. This was due to pollution control in Indonesia, especially Bandung Basin has not been done well, so that the quality conditions are uncertain. The highest value of BOD pollutant parameters in both dry and very dry years is the water-resistance rate in water quality. In this case, the highest value is during the dry year 5-year return period, i.e., 129 $\mathrm{mg} / \mathrm{l}$. Data on the value of quality quantities during dry and very dry years in Figure 6 and Figure $7 \mathrm{can}$ be used as the reference value for the worst water quality BOD parameters for the planning and construction of water resource infrastructure that is more reliable and efficient.

BOD value in the Saguling Reservoir Intake Turbine post by utilizing the Saguling Reservoir discharge is smaller and stable compared to the river flow (natural) in the Nanjung post monitoring site because of the dilution of the pollution concentration influence. It results in the water quality of the waters with a reservoir discharge and volume adjustment and tends to be better than natural river flows. Reservoir water quality is strongly influenced by the environmental quality of the Upstream of the Citarum watershed, while the environmental quality of the watershed is affected by changes in land use. Waste diversity and its increasing or decreasing levels will affect the technical process of water resources infrastructure (Tampubolon et al., 2007). For users of water resources environmental services, decreasing the quantity and quality of chemical water due to increasing environmental degradation causes additional costs incurred by service users to obtain the same level of satisfaction (Tampubolon et al., 2007).

The incoming and measured BOD in Nanjung and Saguling Reservoir comes from activities (domestic, industrial, agriculture, and animal husbandry) in the Bandung Basin, Upstream of the Citarum Watershed. As a result of this pollution, the supply of safe drinking water is increasingly threatened. The disruption of the drinking water supply due to pollution or poor water quality has occurred. Meanwhile, the supply of drinking water has also suffered a decline in quality. Protection of water quality must also be a priority in Indonesia. This approach obviated the need for a treatment plant, saved the city billions of money in capital and ongoing operations and maintenance costs, and preserved a critical ecosystem (Grant et al., 2012).
Unsustainable and unsafe water use patterns highlight the importance of integrated water resource management and the failure of the government to implement integrated water resource management in planning and managing development in the past. With limited water resources, the spatial and temporal characteristics of water availability and pollution control require sufficient and calculated attention in development (Grant et al., 2012). Changing water use patterns and promoting effective implementation of integrated water resource management are important strategies to improve water security in Indonesia. In addition, implementing an independent hydrological and water impact assessment study can help assess/estimate explicitly the availability of water or water quality as a limitation in decision making for social-economic development and to reduce the risk of damage to water (Jiang, 2015).

\section{CONCLUSION}

Water security in the Bandung Basin falls into the category of poor (rare) because the water security index only shows $174 \mathrm{~m}^{3}$ per capita per year. It is based on the quantity of the mainstay discharge of R10 $\left(32.12 \mathrm{~m}^{3} / \mathrm{sec}\right)$ in the Nanjung Post compared to the population in the Bandung Basin, reaching 5.8 million inhabitants. Data of quality in a dry year (R5) of $129 \mathrm{mg} / 1$ and very dry year (R10) of $112 \mathrm{mg} / \mathrm{l}$ can be used as a value for the reliability of water quality of BOD parameters and can be used as a reference for planning and construction of more reliable and efficient water resources infrastructure. Changing water use patterns and promoting effective implementation of integrated water resource management are essential strategies to improve water security in Indonesia.

\section{REFERENCES}

Afifah, E., Sabar, A., Wulandari, S., \& Marselina, M. (2019). The Reliability Study of Raw Water Sources in the Development of Potable Water Supply Systems in Indonesia. GEOMATE Journal, 16(54), 209-216.

Badan Pusat Statistik (BPS). (2011). Statistik Indonesia 2011.

Bakker, K. (2012). Water security: research challenges and opportunities. Science, 337(6097), 914-915.

Bukit, N. T., \& Yusuf, I. A. (2002). Beban pencemaran limbah industri dan status kualitas air sungai citarum. Jurnal Teknologi Lingkungan, 3(2), 98106.

Bulsink, F., Hoekstra, A. Y., \& Booij, M. J. (2010). The water footprint of Indonesian provinces related to the consumption of crop products. Hydrology and Earth System Sciences, 14(1), 119-128. 
Cook, C., \& Bakker, K. (2012). Water security: Debating an emerging paradigm. Global environmental change, 22(1), 94-102.

Corsita, L. (2015). Pengelolaan Waduk Kaskade Citarum Untuk Pengembangan Air Baku Infrastruktur Air Minum DKI Jakarta. Disertasi. Program Studi Teknik Lingkungan Institut Teknologi Bandung.

Falkenmark, M. (1989). The massive water scarcity now threatening Africa: why isn't it being addressed?. Ambio, 112-118.

Falkenmark, M. (2013). Growing water scarcity in agriculture: future challenge to global water security. Philosophical Transactions of the Royal Society A: Mathematical, Physical and Engineering Sciences, 371(2002), 20120410.

Fischer, G., Hizsnyik, E., Tramberend, S., \& Wiberg, D. (2015). Towards indicators for water security-A global hydro-economic classification of water challenges.

Fulazzaky, M. A. (2014). Challenges of integrated water resources management in Indonesia. $\mathrm{Wa}$ ter, 6(7), 2000-2020.

Garrick, D., \& Hall, J. W. (2014). Water security and society: risks, metrics, and pathways. Annual Review of Environment and Resources, 39, 611639.

Gössling, S., Peeters, P., Hall, C. M., Ceron, J. P., Dubois, G., \& Scott, D. (2012). Tourism and water use: Supply, demand, and security. An international review. Tourism management, 33(1), 1-15.

Grant, S. B., Saphores, J. D., Feldman, D. L., Hamilton, A. J., Fletcher, T. D., Cook, P. L., ... \& Marusic, I. (2012). Taking the "waste" out of "wastewater" for human water security and ecosystem sustainability. Science, 337(6095), 681-686.

Hanjra, M. A., \& Qureshi, M. E. (2010). Global water crisis and future food security in an era of climate change. Food policy, 35(5), 365-377.

Head, B., \& Cammerman, N. (2010). The Water-Energy Nexus: A Challenge for Knowledge and Policy. Urban Water Security Research Alliance.

Hoekstra, A. Y., Buurman, J., \& Van Ginkel, K. C. (2018). Urban water security: A review. Environmental research letters, 13(5), 053002.

Indonesian National Water Resources Council (2012). Draft rekomendasi isu strategis ketahanan air. Jakarta: Indonesian National Water Resources Council.

Jiang, Y. (2015). China's water security: current status, emerging challenges and future prospects. Environmental Science \& Policy, 54, 106-125.

Lautze, J., \& Manthrithilake, H. (2012, May). Water security: old concepts, new package, what value?. In Natural Resources Forum (Vol. 36, No. 2, pp. 76-87). Oxford, UK: Blackwell Publishing Ltd.

Loucks, D. P., \& Van Beek, E. (2017). Water resource systems planning and management: An introduction to methods, models, and applications. Springer.
Marganingrum, D., Arwin., Roosmini, D., \& Pradono. (2013). Dampak variabilitas hujan dan konversi lahan terhadap sensitifitas debit aliran Sungai Citarum. Forum Geografi, 27(1), 11-22.

Marganingrum, D. (2013). Integrated water resources management" Saguling Reservoir" in order to adapt the development of Bandung metropolitan area (Dissertation). Environmental Engineering Research Program ITB.

Marselina, M., \& Sabar, A. (2017). Model Prakiraan Debit Air dalam Rangka Optimalisasi Pengelolaan Waduk Saguling-Kaskade Citarum. Jurnal Purifikasi, 17(1).

Mihelcic, J. R., Auer, M. T., Hand, D. W., Honrath, R. E., Perlinger, J. A., Urban, N. R., \& Penn, M. R. (1999). Fundamentals of environmental engineering. John Willey and Sons. Inc.: New York.

Nuraeni, Y. (2011). Metode Memperkirakan Debit Air yang Masuk ke Waduk dengan Metode Stokastik Chain Markov (Contoh Kasus: Pengoperasian Waduk Air Saguling). Jurnal Teoretis dan Terapan Bidang Rekayasa Sipil, 18(2).

Priyambada, I. B., \& Suprapto, R. P. E. (2008). Analisa Pengaruh Perbedaan Fungsi Tata Guna Lahan Terhadap Beban Cemaran BOD Sungai (Studi Kasus: Sungai Serayu-Jawa Tengah). Jurnal Presipitasi: Media Komunikasi dan Pengembangan Teknik Lingkungan, 5(2), 55-62.

Radhika, N., Fauzi, M., Rahmawati, S., Rendy, F., Anthon, F., \& Waluyo, H. (2013). Neraca Ketersediaan Air Permukaan dan Kebutuhan Air pada Wilayah Sungai di Indonesia. Kolokium Hasil Penelitian dan Pengembangan Sumber Daya Air (Pusat Litbang Sumber Daya Air, 2013).

Radhika, F. R., \& Hatmoko, W. (2017). Konsep Indikator Ketahanan Air Irigasi. In Dalam Prosiding Seminar Nasional INACID Jambi-Indonesia (pp. 10-11).

Sabar, A. (2009). Perubahan Iklim, Konversi Lahan, dan Ancaman Banjir dan Kekeringan di Kawasan Terbangun. Pidato Ilmiah Guru Besar ITBMajelis Guru Besar ITB. CV Senatama WikaryaBandung.

Setyono, E., \& Ismijayanti, D. (2015). Prediksi Beban Sedimentasi Waduk Selorejo Menggunakan Debit Ekstrapolasi dengan Rantai Markov. Media Teknik Sipil, 13(1), 37-44.

Sitorus, S., \& Simangunsong, B. (2013). Implementasi Baku Mutu Air Limbah Berbasis Daya Tampung Beban Pencemaran Badan Air Penerima Pada Kegiatan Pertambangan Batubara. Jurnal Kimia Mulawarman, 10(2).

Supangat, A. B., \& Paimin, P. (2016, August). Kajian Peran Waduk Sebagai Pengendali Kualitas Air Secara Alami. In Forum Geografi (Vol. 21, No. 2).

Tampubolon, R., Sanim, B., Sri, S. M., \& Boer, R. (2007). Analisis Perubahan Kualitas Lingkungan Daerah Aliran Sungai Citarum Jawa Barat dan Pengaruhnya Terhadap Biaya Produksi 
PLTA dan PDAM (Studi Kasus PLTA Saguling, PLTA Cirata, PLTA Jatiluhur, PDAM Purwakarta, dan PDAM DKI Jakarta). Jurnal Tanah dan Iklim, 26, 47-62.

Thapa, B. R., Ishidaira, H., Pandey, V. P., Bhandari, T. M., \& Shakya, N. M. (2018). Evaluation of water security in Kathmandu Valley before and after water transfer from another basin. Water, 10(2), 224

van Noordwijk, M., Kim, Y. S., Leimona, B., Hairiah, K., \& Fisher, L. A. (2016). Metrics of water security, adaptive capacity, and agroforestry in Indonesia. Current Opinion in Environmental Sustainability, 21, 1-8.

Vörösmarty, C. J., McIntyre, P. B., Gessner, M. O., Dudgeon, D., Prusevich, A., Green, P., ... \& Davies, P. M. (2010). Global threats to human water security and river biodiversity. $\mathrm{Na}$ ture, 467(7315), 555-561.
Water, U. N. (2016). Water scarcity. New York: United Nations.

Wheater, H. S., \& Gober, P. (2015). Water security and the science agenda. Water Resources Research, 51(7), 5406-5424.

World Health Organization (WHO). (2014). UN-water global analysis and assessment of sanitation and drinking-water (GLAAS) 2014 report: investing in water and sanitation: increasing access, reducing inequalities.

Xia, J., Zhang, L., Liu, C., \& Yu, J. (2007). Towards better water security in North China. Water Resources Management, 21(1), 233-247.

Zeitoun, M., Allan, J. T., \& Mohieldeen, Y. (2010). Virtual water 'flows' of the Nile Basin, 1998-2004: A first approximation and implications for water security. Global Environmental Change, 20(2), 229-242. 